\title{
Chemical Course System Construction and Practice of Food Science and Engineering Major
}

\author{
Ning Ma ${ }^{1,}$, , Hui Shang ${ }^{1}$ \\ ${ }^{1}$ College of Food Science and Engineering, Nanjing University of Finance and Economics, Nanjing, \\ 210023, China. \\ ae-mning@nufe.edu.cn
}

\begin{abstract}
Based on the analysis of the talent demand situation in food science and engineering major as well as the position and function of the basic chemistry course system in talent training of the major, in view of the chemical course system construction and practice in the course system of food science and engineering major in Nanjing University of Finance and Economics, this paper puts forward the systematic credit hour and academic credit distribution of chemical courses in the course of food science and engineering, and provides reference for the setting of chemical course system of the undergraduate major of food science and engineering in Chinese institutions of higher learning.
\end{abstract}

Keywords: Food science and engineering major, chemistry course, course system.

\section{Introduction}

Food science and engineering major is an applied major with strong practicality, and also an integrated inter-discipline. The major has covered the contents of chemistry, biology, food engineering and food technology, and applied technologies in modern biotechnology such as cell fusion, microbial breeding and biochip to food engineering. With the development of modern science and technology, modern food science and engineering major has gotten rapid development. Up to now, according to the statistics, more than 200 colleges and universities have set up the major of food science and engineering, and formed training systems in different levels for junior college students, undergraduates, masters, doctors and so on. The setting of the course system of food science and engineering major plays a critical role in training students' knowledge capability and their successful job-hunting. Moreover, the course system and the content of course are also the core of training talent quality and improving the quality of teaching [1]. Therefore, many scholars investigated the course system setting, practical teaching and talent training model of food science and engineering major, and put forward "student-oriented", the goal of "cultivating application-oriented talents of engineering with strong manipulative ability and creative spirit" and the basic principle of "wide scope culture, with focus on foundation and quality" [2-6]. But few scholars discussed links such as the construction, reform and practice of basic chemistry course system, which is the most important in food science and engineering major.

Chemistry course is the foundation course of food science. It is generally believed that teachers only need to teach several traditional elementary courses well, including general chemistry, organic chemistry and physical chemistry and its experiments, the training of students' ability and quality is a matter of the related majors, and no much attention has been paid to the methods of carrying out systematic reform and the intensity of reform is small. Since the new century, especially since the Ministry of Education continuously made progress in the construction of quality engineering, related teaching administrative departments and teachers who have long engaged in the front-line teaching have universally recognized the seriousness of the problem. As chemistry is an important elementary course of food science, it has been playing a vital function in cultivating students' ability and quality, and plays an irreplaceable role in cultivating students' scientific thinking, practical ability and learning habits, the significance of chemistry as a basic subject is embodied more when students gradually start professional study, and then master and doctoral study. Therefore, it is necessary to take the cultivation of high-quality applied talents with reasonable knowledge structure and ability structure as well as excellent scientific research reserve talents not afraid to innovate as the goal, and carry out 
the construction of chemical course system and the reform of teaching content in food science and engineering major.

At present, the school has taken into full consideration the characteristics of food science and engineering major, the core course system conforms to the training standards of food science and engineering course system raised by the Ministry of Education, and possesses the characteristics and advantages of food science and engineering major of Nanjing University of Finance and Economics. According to the cultivation of students' core competence, the core courses of the major are divided into four modules, including professional basic courses, professional main courses, professional restricted optional courses and practical teaching. The course of professional basic chemistry covers inorganic and analytical chemistry, biochemistry, organic chemistry and physical chemistry. The practical teaching includes inorganic and analytical experiments, organic analytic experiments, biochemistry experiments and physical chemistry experiments. The teaching program should be adjusted to make the content of basic chemistry courses meet the learning needs of follow-up professional courses of the major. Based on the teaching practices of basic chemistry courses of food science and engineering major in recent years, being the demand for professionals in enterprises and market oriented, in view of the problems that have not yet been completely solved in basic chemistry courses of food science and engineering major in a number of colleges and universities, such as some out-dated and repeated contents, the teaching content laying particular stress on chemical theories and the discrepancy between the content of food science, this paper puts forward recommendations on the construction and reform of chemical course system of food science and engineering major, and provides a reference for the strategy of training talents with good professional skills and strong innovative abilities.

\section{Talent Demand Status in Food Science and Engineering Major}

Food industry is one of the largest industrial sectors in China. The industry involves a wide range of fields and has complex division of labor and large system, and enterprises in the industry are in various scales and under rapid and unbalanced development, which makes the industry have peculiar demand for talents, knowledge, ability and quality. As the main channels for talent cultivation of food science and engineering major, institutions of higher learning are required to closely link up the training of professional talents with social needs. Therefore, the undergraduate training plan of food science and engineering major in institutions of higher learning should meet the talent demand in China's food industry. At present, from the perspective of the operating posts in which students of food science and engineering major engage, the employment channels are diversified, and the students mainly work on food production technology management, quality control, hygiene and disease control, commodity inspection, biochemical engineering and food processing [7]. Through the investigation on the employment status of graduates of several sessions, the recruiting units of relevant posts all pay great attention to the requirements for students' study of chemical basic courses. Even the content of professional skill testing in the interview link of epidemic prevention and commodity inspection units involves the chemistry experiments and the chemical analytical and testing skills that students do or master during university. Therefore, the status and reasonable setting of chemical course system in food science and engineering major should be attached importance to by all universities.

\section{The Status and Function of Basic Chemical Course System in Talent Training of Food Science and Engineering Major}

Chemistry is a basic subject of science. It has the characteristics of fundamentality, applicability and innovativeness, and it is a very important basic course of food science and engineering major. In recent years, the non-chemistry majors in some colleges and universities in China have carried out various reforms and practices in the teaching system and content of basic chemistry. For example, for the purpose of strengthening chemical practices, Nanjing Agricultural University has established 
the new model of basic chemistry practical teaching, which covers basic chemistry experiments, chemical practical training, chemical practices and graduation thesis design, and deepened the reform and innovation of chemical experiment teaching with the course system and teaching content of "basic, comprehensive, design and open" chemical experiment teaching practices as the main clue [8]. The Northeast Agricultural University has integrated six basic chemistry experiment courses, established the network teaching platform and electronic courseware resources of a series of experimental courses of basic chemistry, constructed the "integrated, multi-layered and open" new teaching system and stereoscopic teaching model for a series of experimental courses of basic chemistry, promoted green experiment, and set up open and comprehensive experiment [9]. In order to take full advantage of the limited credit hours, Fujian Agriculture and Forestry University combined the originally 51-hour inorganic chemistry with 34-hour analytical chemistry into the 64-hour new course of "Introduction to Chemistry" [10]. Although some scholars have reformed and investigated the course setting of food science and engineering major, few discussions on the system settings of the basic chemistry course system have been carried out $[6,11]$. Basic chemical course system includes inorganic and analytical chemistry, inorganic and analytical chemistry experiments, organic chemistry, organic chemistry experiments, and the basic chemistry courses of physical chemistry, which enables students to closely connect the basic chemical theoretical knowledge with the processing and application of food, plays a bridge role, lays a solid foundation for students' study of follow-up specialized courses and plays a crucial function in training college students' entrepreneurship and innovation skills. Therefore, it is imperative to establish a reasonable, systematic and standardized chemistry course system for food science and engineering major.

\section{The Establishment of A Reasonable, Systematic and Standardized Chemistry Course System for Food Science and Engineering Major}

The major of food science and engineering of the school is the national featured major, the core major under the construction of Jiangsu key specialties during the 12th Five-Year Plan period and brand specialty in Jiangsu universities. The major has obtained master's degree awarded qualification of food science and engineering major in 2006. At present, there are 14 employees in the department of food science and engineering of the school. There into, there are 10 master tutors, 6 professors, 4 associate professors and 4 lecturers, $64 \%$ of the employees have doctorate, $36 \%$ have master's degree, and the faculty structure is reasonable.

\subsection{Combination with the Training Objectives and Adjustment of the Course Settings}

Chemical course is an important basic course of the food major, but there are some problems in the teaching process, for instance, the teachers' understanding of the objective of talents training of food major is incorrect, the syllabus of basic chemistry courses cannot be in effective agreement with the professional course syllabus, the credit hours are numerous, and the connection degree with professional practices is insufficient. Taking into full consideration the characteristics of food science and engineering major, in view of the school training objective of applied, inter-disciplinary and innovative talents with solid foundation, strong ability, high quality and all-round development of morality, intelligence physique and aesthetics, the existing teaching program has been systematically set in 2016 (Table 1), so that the chemical course system conforms to the training standards of the course system of food science and engineering major, which were formulated by the Ministry of Education, and possesses the characteristics and advantages of food science and engineering major of Nanjing University of Finance and Economics. According to the cultivation of students' core competence, the core courses are divided into four modules, including professional basic courses, professional main courses, professional restricted elective courses and practical teaching. At present, the above course setting has been implemented. The investigation on the students showed that $95 \%$ of the students think that the setting of the chemistry course system is reasonable. Furthermore, the investigation on professional teachers was conducted and the teachers generally consider that the students have solid chemistry foundation and show obvious enthusiasm for the study of professional 
courses. Moreover, the results of online teaching evaluation indicate that the teaching of chemistry courses ranks top.

Table 1. Setting and Distribution of Chemistry Course System in the Undergraduate Major of Food Science and Engineering

\begin{tabular}{|c|c|c|c|c|}
\hline Course Nature & Course Name & $\begin{array}{l}\text { Credit Hour } \\
\text { (Practical } \\
\text { Teaching) }\end{array}$ & $\begin{array}{l}\text { Hours } \\
\text { Allocation } \\
\text { (Practical } \\
\text { Teaching) }\end{array}$ & $\begin{array}{c}\text { Ratio of Hours to Total } \\
\text { Hours in Corresponding } \\
\text { Module }\end{array}$ \\
\hline \multirow{8}{*}{$\begin{array}{l}\text { Professional } \\
\text { Basic Courses }\end{array}$} & $\begin{array}{c}\text { Inorganic and } \\
\text { Analytical Chemistry } \\
1\end{array}$ & 3 & 51 & $12 \%$ \\
\hline & $\begin{array}{c}\text { Inorganic And } \\
\text { Analytical Chemistry } \\
\text { Experiment } 1\end{array}$ & $2(2)$ & $34(34)$ & $8 \%$ \\
\hline & Organic Chemistry & 3 & 51 & $12 \%$ \\
\hline & $\begin{array}{l}\text { Organic Chemistry } \\
\text { Experiment }\end{array}$ & $2(2)$ & $34(34)$ & $8 \%$ \\
\hline & $\begin{array}{l}\text { Inorganic And } \\
\text { Analytical Chemistry } \\
\text { Experiment } 2 \\
\text { Inorganic And }\end{array}$ & $2(2)$ & $34(34)$ & $8 \%$ \\
\hline & $\begin{array}{l}\text { Analytical Chemistry } \\
\qquad 2\end{array}$ & 2 & 34 & $8 \%$ \\
\hline & Biochemistry & 3 & 51 & $12 \%$ \\
\hline & $\begin{array}{l}\text { Biochemistry } \\
\text { Experiment }\end{array}$ & 2(2) & $34(34)$ & $8 \%$ \\
\hline \multirow{4}{*}{$\begin{array}{c}\text { Professional } \\
\text { Main Courses } \\
\text { Professional } \\
\text { Restricted } \\
\text { Elective } \\
\text { Courses }\end{array}$} & Food Analysis & $3(3)$ & $51(51)$ & $12.5 \%$ \\
\hline & Food Chemistry & $3(1)$ & $51(17)$ & $12.5 \%$ \\
\hline & Physical Chemistry & $4(1)$ & $68(17)$ & $17.3 \%$ \\
\hline & $\begin{array}{l}\text { Instrumental } \\
\text { Chemistry }\end{array}$ & $3(1)$ & 51 & $13 \%$ \\
\hline Total & & $32(14)$ & $544(221)$ & $\begin{array}{l}21 \% \text { (Ratio to Total Hours } \\
\text { in the Whole Module) }\end{array}$ \\
\hline
\end{tabular}

\subsection{Breaking Course Boundary and Integrating Teaching Content}

Many of the contents in the four major chemical systems repeatedly appear, such as acid-base theory, chemical equilibrium, chemical reaction thermodynamics, chemical reaction kinetics, redox reaction and coordination reaction. Due to self-developed systems, different teachers repeatedly explain the same knowledge point. In order to solve these problems, teachers of basic chemistry courses and food science and engineering professional courses should be organized to carry out panel discussions, to investigate and survey in other colleges and universities, to master the contents that are repeatedly taught, missed or improperly connected in the basic chemistry courses of food science and engineering major in the institute, and to comprehensively understand the chemical contents that must be taught in the teaching process of this major. Besides, the teachers are required to integrate related resources of the chemistry courses and set up a digital database of the basic chemistry courses. For basic courses such as inorganic chemistry, analytical chemistry, organic chemistry and physical chemistry of food science and engineering major, a multi-layered and "basic, improved, integrated and innovative" course system should be constructed. For example, the teaching contents of acidbase theory and the basic principles of redox and coordination reaction that are repeated in inorganic chemistry and analytical chemistry can be optimized and integrated, and the basic principles of chemical reactions can be combined with quantitative analysis methods. In three aspects of the structure, property and application of compounds, the essence of inorganic and organic substances 
should be understood at both micro and macro levels. The parts of the thermodynamics and dynamics basis of inorganic chemistry and physical chemistry can be integrated, the basic theories and elementary knowledge of chemical reactions can be stressed, the physical processes can be downplayed, the macroscopic laws of chemical changes can be explored, and the redox content can be combined with electrochemical principles.

\subsection{The Experience of Blended Teaching of Inorganic Chemistry and Analytical Chemistry}

The Ten-Year Plan of Educational Informationization (2011-2020) proposes to focus on the deep integration of information technology and higher education, promote the modernization of educational content and teaching means and methods, innovate the mode of talent training, scientific research organizations and social services, promote cultural inheritance and innovation, and accelerate the all-round improvement of the quality of higher education. Teachers of this institution carry out meticulous design of different teaching contents, and choose inorganic chemistry and analytical chemistry experimental courses to make the teaching module of "micro-course". Using the teaching mode of "micro-course", interdisciplinary contents, relatively independent contents and key and difficult knowledge points can be displayed more intuitively and quickly. In the teaching of each class, several teaching methods should be combined and applied, and meanwhile, students should be guided to apply the method of induction and comparison to incorporate new knowledge into the original knowledge system, so that a knowledge network from point to line and from line to plane can be constructed, the internal connection between knowledge points and the laws can be figured out, and good teaching efficiency can be achieved. Since the practice of blended teaching was set up in the course teaching of inorganic chemistry and analytical chemistry, obvious effects have been achieved in aspects of students' knowledge accumulation, the cultivation of innovative thinking and the enhancement of autonomous learning ability. In addition, the micro-course of "the generality of solution" designed by members of the research group won second class prize in the second Jiangsu college teacher public artistic micro-course competition in 2018. Furthermore, the new model of "mobile phone plus" analytical chemistry experimental teaching has been approved and adopted in the school demonstration classroom construction project.

\section{Conclusion}

The reform and setting of the chemistry course system is adapted to the mode of "wide scope culture, with focus on foundation and quality" of talent training in food science and engineering major, and conforms to the demand for talents majoring in food science and engineering in China. Practice shows that the setting of chemistry course system of the school has played a positive role in the teaching of food science and engineering major and been recognized by the students. Besides, it provides some reference for the construction, reform and practice of chemical course system of food science and engineering major in other institutions of higher learning in China.

\section{Acknowledgements}

The authors acknowledge financial support from School-level education reform project in Nanjing University of Finance and Economics (JGY1740) and Top-notch Academic Programs Project Jiangsu Higher Education Institutions (Grant No. PPZY2015B152).

\section{References}

[1]. Zhang Zheng, Zhou Tina, Hai Jinxing, et al. Being employment-oriented, strengthening engineering quality-talent training program and course system reform and practice of food science and engineering major [J]. Value Engineering, Vol. 30 (2011) No. 30, p. 174-175. 
[2]. Jiang Chichi, Qi Song Shan, Zhang Zheng, et al. OBE educational idea based teaching reform and discussion of food science and engineering major [J]. Agriculture Products Processing, (2016) No. 3, p. 79-81.

[3]. Li Chen, Zhang Xinhua, Fan Sandhog. Exploration on practical teaching reform of food science and engineering major [J]. Agriculture Products Processing, (2016) No. 24, p. 77-79.

[4]. Ni Li, Wang Qu, Zhang Wen, et al. The construction and practice of engineering education professional certification-oriented multi-dimensional practical teaching system of food science and engineering major [J]. Fujian Qing Fang, (2017) No. 6, p. 35-38.

[5]. Zhao Jian fen, Liu Zhao, Liang Qiaorong. The optimization and innovation of the practical teaching system of food science and engineering major under the background of university transformation development [J]. Guangdong Chemical Industry, (2018) No. 1, p. 233-234.

[6]. Guang-Cai Nia, Hong-HI Yang, Xian-Qing Wang, et al. The construction and implementation of the innovative practice teaching system of food science and engineering major [J]. Food and Machinery, (2013) No.5, p. 270-272.

[7]. Chen Minden, Fang Tuna, Cong Deli. Teaching and learning of principles of chemical engineering [M]. Chemical Industry Press, 1996, p. 231-236.

[8]. Yang Hong, Yang Chilung, Land Yawing, et al. Basic chemical practice teaching reform in agricultural or forestry colleges [J]. University Chemistry, Vol. 25(2010) No.4, p. 19-21.

[9]. Fu Ying, Ye Fee. The optimization of basic chemistry experiment course system [J]. University Chemistry, Vol. 28 (2013) No. 2, p. 25-28.

[10]. Yang Guide, Pan Jingle, Li Jay, et al. The reform exploration of chemistry basic courses of biological majors in agricultural or forestry colleges [J]. Chinese Forest Education, Vol. 30 (2012) No. 2, p. 76-78.

[11]. Goo Nan, Zhang Na, Li Liming. Teaching reform research of chemical courses in food major teaching [J]. Guangzhou Chemical Industry, (2015) No. 23, p. 281-282. 